\title{
BOZSÓ ZOLTÁN
}

\section{A rendőrségi tevékenységirányítás fejlesztésének lehetőségei}

\begin{abstract}
A Nemzeti Közszolgálati Egyetemen megvédett doktori értekezésemben áttekintettem a tevékenységirányítás különböző területeit, kiemelve a rendezvények és a különleges helyzetek kezelését. Bemutattam az alkalmazott csapaterö összetételét, feladatait, a szervezés és irányítás sokszínűségét.

A rendezvények rendjének fenntartásában a csapaterö ${ }^{\prime}$ a rendezvény szervezőjének írásbeli felkérése, vagy ha a közbiztonsági helyzet, a szabálysértések és bủncselekmények megelőzése indokolja, a területileg illetékes rendörkapitány, rendőrfőkapitány döntése alapján, a szervezővel történő elözetes egyeztetés után közremüködhet. A felkérés teljesítéséről vagy elutasításáról a rendőr(fö)kapitány határoz.
\end{abstract}

\section{A vezetési pont}

Vezetési pont, a helyi körülményektől függően, a rendezvény helyszínén belül vagy közvetlenül mellette, a közönség elöl elzárt, védett helyen helyezkedik el. A helyszínen, annak egy magas, jó rálátást engedő pontján külön figyelőpontot is berendezhetnek, ahol a rendezvény időszakában a biztosítás parancsnoka és néhány segítője tartózkodhat. A figyelőpont berendezése lehetővé teszi az állandó híradó- és esetleg a képi információs összeköttetést valamennyi alárendelttel, valamint a vezetési pont többi elemével.

\section{Belső biztosító csoportosítás}

Belső biztosító csoportosítás állományába a beléptető pontokon a belépési jogosultságot ellenőrző, a biztonsági ellenőrzést végző rendezők mellett szolgálatot teljesítő biztosító őrök, az egyes szektorokban a rend fenntartásáért felelős biztosítócsoportok, rendfenntartó járőrök, a rendbontók kiemelését

$1 \mathrm{Az}$ a szervezett rendőri kötelék (alegység), amely a biztosításban részt vesz. 
végző kiemelő csoportok, lezárt területre a behatolást megakadályozó záró csoportok, a kijelölt személyek védelmét ellátó fedező csoport, valamint a belső biztosítás tartaléka tartozhat.

\section{Külső biztosító csoportosítás}

Külső biztosító csoportosítás záró csoportokból, a parkolóhelyeken biztosító őrökből, rendfenntartó és biztosító járőrökből, forgalomirányítókból és a külső biztosító csoportosítás tartalékából állhat.

\section{Közvetlen alárendeltek}

A biztosítás parancsnoka a saját közvetlen alárendeltségében tarthatja az események képi rögzítését végző dokumentációs csoportot, a felderítő, büncselekmény-megelőző tevékenységet folytató bünügyi nyomozókat és a polgári ruhás közbiztonsági felderítő csoportot, továbbá a biztosítás folyamán a tömeg közül kiemelt jogsértő személyeket a rendőrségi objektumba, vagy külön, a helyszínen kijelölt előállító helyre kísérő előállító csoportot, az adott település egész területére kiterjedően feladatokat ellátó közlekedésrendészeti csoportot, a kísérő, elválasztó, az összetüzéseket megakadályozó biztosítócsoportokat, a kiemelt objektumok őrzését ellátó biztosító-, illetve rendfenntartó csoportokat és az egyéb közrendvédelmi járőrszolgálatokat.

\section{Tartalék}

A biztosítás parancsnokának tartaléka készen áll a különböző szolgálati csoportok megerősítésére, feladataik részbeni vagy teljes átvételére, valamint nagyobb rendbontó csoportosulás elleni határozott fellépésre. A tartalék nagysága általában az összevont rendőri létszám tíz-tizenöt százaléka. Szükség esetén a biztosítás körzetében más önálló szolgálati és anyagi, technikai, egészségügyi biztosítócsoportok is alkalmazhatók. 


\section{A rendezvénybiztosítás végrehajtása}

A rendezvények rendjének fenntartásában közremüködő, területileg illetékes rendőri szerv vezetöje a rendezvény szervezőjével vagy a rendezvénynek helyet adó létesítmény üzemeltetőjével írásbeli megállapodás ${ }^{2}$ keretében vállalja, hogy

- a rendőri biztosítás parancsnoka és törzse számára a rendezvény helyszínének megfigyelését biztosító, vezetési pontnak (figyelöpont) alkalmas terület, építmény vagy helyiség álljon rendelkezésre;

- biztosított legyen a rendörségi technikai eszközök védett elhelyezése;

- a rendezvény (létesítmény) hangosító berendezését a biztosítás parancsnoka szükség esetén azonnal és közvetlenül igénybe tudja venni;

- a képrögzítő technikai eszközök telepítése, illetve a létesítmény tulajdonában álló, beépített, zárt láncú televízióberendezések korlátozás nélküli igénybevétele biztosított legyen;

- álljanak rendelkezésre a létesítmény alaprajzára, főbb műszaki paramétereire, biztonsági berendezettségére vonatkozó adatok.

A rendezvénybiztosítás tervének tartalmaznia kell:

- a rendezvényről rendelkezésre álló adatokat (a rendezvény megnevezését, megtartásának helyét, kezdetének és befejezésének időpontját, a résztvevők várható létszámát, összetételét, a rendezvény programját, a rendező szerv felelős megbízottjának nevét, címét, a rendezvény alatti tartózkodási helyét, a vele való összeköttetés rendjét);

- a közbiztonsági helyzet értékelését (a rendezvény megzavarására, jogellenes cselekmények elkövetésére irányuló előkészületekről, a korábbi hasonló rendezvények tapasztalatairól rendelkezésre álló adatokat és az abból levont rövid következtetéseket);

- a rendőri biztosítás elgondolását (a rendőri biztosítás módja, célja, időszakai, milyen fö feladatokra kell a figyelmet fordítani, a biztosítás körzete, a rendelkezésre álló erők és eszközök, az azokból létrehozott csoportosítások, a tervezett átcsoportosítások, összevonások rendje, a bevezetésre tervezett biztonsági és korlátozó rendszabályok, a kényszerítő intézkedések bevezetésének rendje, az alkalmazásra tervezett kényszerítő eszközök);

- a biztosítás parancsnoki állományát és a szolgálati csoportok megalakításának rendjét (parancsnok, beosztott létszám és technikai eszköz, feladat);

2 Csapatszolgálati Szabályzat. 11/1998. ORFK Utasítás. 
- a szolgálati csoportok feladatait;

- a személyi állomány felkészitésének és eligazításának rendjét, szempontjait és azok rövid tartalmát;

- a magatartási rendszabályokat jogsértő cselekmények elkövetése esetén;

- az együttmüködés és a mindenoldalú biztosítás rendjét (az együttmüködés feladatai a biztosítószolgálat egyes időszakaiban és azok tartalma a jogsértő cselekmények felfedése, dokumentálása, a vezetési és információs rendszer védelmi, a saját erők és eszközök megóvása, az anyagi ellátás, a személyi állomány öltözete, felszerelése, fegyverzete, a technikai eszközök kiszolgálása, a személyi állomány egészségügyi biztosítása érdekében végrehajtandó feladatok);

- a készenléti és más főbb időpontokat;

- a jelentések rendjét (ki, mikor, kinek, mit hogyan jelentsen szóban és írásban);

- a vezetés rendjét (a vezetési pont hová települ, a figyelöpont helye, az esetleges áttelepülés rendje, ideje, a vezetés átvételének rendje a vezetési pont kiesése esetén).

A rendezvénybiztosítás tervének mellékleteként ${ }^{3}$ vázlatot (vázlatokat) kell készíteni, amely tartalmazza:

- a helyszín, létesítmény közvetlen és távolabbi környezetét, a fokozott ellenőrzés alá vont területeket, parkolóhelyeket, megközelítési útvonalakat, a tömegközlekedési eszközök megállóhelyeit, haladási irányait, az ellenőrzést igénylő csomópontokat és más kiemelt, illetve védett objektumokat, lezárt útszakaszokat, a forgalomterelés irányait;

- a létesítmény alaprajzát, a nézőtér szektorokra bontását, befogadóképességét ülő- és állóhelyek szerint, bejáratokat és vészkijáratokat, a résztvevők elkülönítését lehetővé tevő berendezéseket, mozgási lehetőségeiket, a tüzcsapok és tüzoltó készülékek helyét, büfét, kommunális létesítményeket, elsősegélyhelyet, a veszélyhelyzet esetén rendelkezésre álló kiürítési irányokat);

- a vezetési pontot, az alárendelt parancsnokok tartózkodási helyét, az egyes szolgálati csoportok müködési helyét, körzetét, útvonalát, összpontosítási, megindulási, várakozási, gyülekezési körleteit, feladatait, a tartalékok elhelyezkedését, alkalmazási terepszakaszokat, az előállítás helyét, az alegységek mozgatásának menetvonalát;

- a rendező szerv részéről kijelölt felelős személy tartózkodási helyét.

3 Uo. 
A biztosítási tervhez mellékelni kell továbbá a személyeket és az anyagi javakat közvetlenül fenyegető veszélyhelyzet esetén a létesítmény kiürítésének, illetve a jogellenes magatartást tanúsító tömeg feloszlatásának tervét (a tömegoszlatási terv).

\section{Fokozott ellenőrzés a rendezvény körzetében}

A rendezvény helyszínének beléptetőpontjain (bejáratok) a közbiztonságra különösen veszélyes eszközök felfedése, bevitelük megakadályozása, az eszközöket birtoklókkal szemben szükséges eljárások kezdeményezése érdekében a belépők ruházatának, csomagjának, szükség esetén jármüveinek átvizsgálását kell végrehajtani. Az átvizsgálást a rendezők végzik, tevékenységük segítésére biztosító járőröket kell alkalmazni. A közbiztonságra különösen veszélyes eszközök ${ }^{4}$ körén túl, szükség esetén a rendőri szerv vezetöje kezdeményezi, hogy a rendezvény szervezője a biztonságra veszélyt jelentő más eszközök (például esernyő, sétabot, zászlórúd stb.) bevitelét tiltsa meg, és azokat a rendezvény végéig helyeztesse letétbe. A letétbe helyezett tárgyak kezelését, megőrzését és visszaszolgáltatását a rendezők végzik. A rendezvény körzetében fokozott rendőri jelenlétet kell biztosítani. Kiemelt figyelmet kell fordítani a jegyárusító helyek, a parkolóhelyek, az engedély (jegy) nélküli bejutásra alkalmas helyek biztosítására, sportrendezvényeken a szurkolótáborok elválasztására. A hatékonyság növelése érdekében a létesítmény és a rendőrség birtokában lévő kordoneszközök széleskörüen alkalmazhatók.

Gondoskodni kell arról, hogy a szükséges beavatkozások végrehajtásához a rendőri erők birtokában legyenek a szükséges feltételeknek. Ennek érdekében a külső zárási, forgalomszervezési, parkolási rendet úgy kell megállapítani, hogy a rendőr alegységek, a szolgálati csoportok részére a szabad mozgási (kijutási, manőverezési) lehetőségek meglegyenek. A szolgálati állatok elsősorban a külső biztosítócsoport állományában alkalmazhatók. Lovas rendőrt sportlétesítmény belső területére (a pályára) vezényelni tilos!

4 175/2003. (X. 28.) kormányrendelet 


\section{Rendőri intézkedések a rendezvény helyszínén és azon kívül}

A különböző rendőri biztosítások alkalmával nagyon fontos a rendezvények előtti megfelelő felkészülés, a különböző egyeztetések lefolytatása és az alapos, személyre szabott feladatmeghatározás, illetve eligazítás. A következőkben kifejezetten a különböző sportlétesítményeken belüli rendőri intézkedésekkel kívánok foglalkozni, és nem térek ki részletesen az egyéb jellegü feladatokra.

„Az új helyzetben a rendörségnek ugyanúgy, mint a többi intézménynek, egyszerre három nehéz feladattal kell szembenéznie: a múlt örökségével, az új helyzetböl fakadó kihivásokkal és eközben a szemléleti és szerkezeti átalakitás problémáival."

A sportrendezvényeken a rendőrséget (a rendőrt) intézkedési kötelezettség akkor terheli, amikor olyan tényt vagy körülményt észlel, illetve hoznak tudomására, amely rendőri beavatkozást igényel. Rendőri beavatkozást igénylő ténynek vagy körülménynek kell tekinteni:

- a büncselekményeket;

- a szabálysértéseket;

- felkérésre más személy igazoltatását, ha az igazoltatást kérő valószínűsíti, hogy az igazoltatáshoz jogos érdeke füződik;

- a közbiztonságra különösen veszélyes anyagok, eszközök lefoglalását (illetőleg azoknak a rendezvény helyszínére bevitelének megtiltását, ez a feladat a beléptetést végző személyzet dolga);

- a nyilvános forgalom számára nyitva álló helyen örizetlenül hagyott, a közbiztonságra veszélyt jelentő tárgy eltávolítását, megsemmisítését;

- önmagát vagy mást veszélyeztető állapotban lévő személy elszállítását, az öngyilkosság lehetőség szerinti megakadályozását, a magatehetetlen, önkívületben lévő személyt lakásra, kijózanítóállomásra, egészségügyi intézetbe kísérését, szállíttatását;

- a balesetveszély megelőzése érdekében a közút forgalmának irányítását, korlátozását, illetve szüneteltetését a feltétlenül szükséges mértékben és időtartamra;

- személyeket, illetőleg anyagi javakat közvetlenül fenyegető veszélyhelyzet elhárítását, ennek megszüntetése érdekében a terület lezárását, oda a belépés vagy eltávozás megakadályozását, illetve az ott tartózkodók távozásra kötelezését.

5 Dános Valér - Tauber István: Rendőrség és társadalom. Rendészeti Szemle, 1993/2. 
„A rendöri munkának mindig voltak, vannak és lesznek olyan feladatai, amelyek nem népszerüek, különösen azok (és rokonságuk, a korábbi kapcsolataik) körében, akikkel szemben alkalmazzák. "'

Kiemelten fontos a sportlétesítményekben a személyeket és anyagi javakat közvetlenül fenyegető veszélyhelyzetek elhárítása, amelyek súlyos problémát okozhatnak. Így például:

- a nézőknek az engedélyezett stadionkapacitáson (szektor befogadóképességén) felüli beléptetése, behatolása, összezsúfolódása;

- a szektorelválasztók, illetve a játékteret a nézőtértől elválasztó kerítés, a menekülőkapuk mérkőzés alatti bedöntése, átszakítása;

- a feljárók, lépcsők eltorlaszolása, lelátók, korlátok, támfalak, kerítések, állványzatok, oszlopok túlterhelését, megrokkanását, a lezuhanás, omlás vagy leszakadás közvetlen veszélyét;

- az építmények, berendezési tárgyak tömeges méretü, felfegyverkezésre irányuló megbontása, megrongálása;

- a szurkolótáborok között vagy azokon belül kialakuló tömegverekedések;

- a csapatok, játékvezetők, illetve más közremüködök elleni közvetlen támadás;

- a keletkezett tüzek terjedését.

A biztosítás parancsnoka köteles a rendezvényen jelen lenni, figyelemmel kísérni a közönség magatartását (vizuálisan vagy kamerák segítségével), és a létesítmény belső rendjét sértő cselekmények esetén hívja fel a szervező figyelmét a rend helyreállítására. A rendőri beavatkozást igénylő körülmények esetén a szükséges erők átcsoportosítására, helyszínre irányítására, a szükséges intézkedések megtételére haladéktalanul intézkednie kell.

„De a rendöri beavatkozás nemcsak a társadalom szervezeteinek védelmét szolgálja, hanem az egyénekét, a polgárokét is." "

\section{Sportrendezvények biztosítása}

A sportrendezvények nyugalmának megőrzése, a közönség által elkövetett rendbontások megelőzése évek óta a hazai és nemzetközi szakmai fórumok állandó témája. Különösen előtérbe került ez a probléma a labdarúgó-mérkőzések vonatkozásában, ahol több tömegkatasztrófa hívta fel a figyelmet e

6 Uo

7 Balla Zoltán: A belső rend és a közrend fogalma jogszabályokban. Belügyi Szemle, 2002/2. 
probléma megoldásának sürgősségére. Az UEFA 1993-ban külön utasításokat alkotott a biztonság fenntartása érdekében, ezek be nem tartása fegyelmi büntetéssel sújtható. A nemzetközi szövetség állásfoglalása szerint a rendezők, a szövetségek és az egyesületek vállalják a felelősséget minden szervezési feladatért ${ }^{8}$. Különösen a mérkőzés rendezőinek - legyen az szövetség, egyesület vagy más testület - a felelőssége az, hogy lehetőségeihez mérten mindent megtegyen a stadionban és annak környékén a mérkőzés előtt, alatt és után a rend és a biztonság fenntartásáért. Ezt a felelősséget a hazai mérkőzések esetén is elötérbe kell helyezni.

\section{A rendezvények biztonsági kategóriái}

Az UEFA által szervezett különböző labdarúgótornák mérkőzéseit a biztonsági kockázat szempontjából két kategóriába sorolták.

A fokozott kockázattal járó mérkőzések kategóriájába a következő találkozók tartoznak:

- az összes UEFA-döntő mérkőzés, a Kupagyőztesek Európa-kupája és az UEFA-kupa elődöntő és negyeddöntő mérkőzései, a Bajnokok Ligája öszszes mérkőzése, a labdarúgó-Európa-bajnokság összes selejtező mérkőzése és döntő fordulóbeli mérkőzése;

- azok a mérkőzések, amelyeket az egyik vagy mindkét csapat szurkolóinak korábbi rendbontó magatartása vagy egyéb rendkívüli ok miatt az UEFA vagy a helyi nemzeti labdarúgó-szövetség ebbe a kategóriába sorol;

- ha várható, hogy a vendégcsapat szurkolóinak száma meghaladja a stadion teljes befogadóképességének tíz százalékát, vagy a háromezer föt. Ha egy mérkőzést semleges helyszínen rendeznek, akkor mindkét csapat vendégcsapatnak tekintendö;

- ha a stadionban telt ház várható, azaz a teljes engedélyezett stadionkapacitás feltöltése vagy több mint huszonötezer néző várható;

- ha várható, hogy a mérkőzésre nagyszámú, a vendégcsapat országából származó ember érkezik, akik a mérkőzést rendező vagy a szomszédos országokban laknak.

Az UEFA-besorolás szerint normál kockázatú mérkőzésnek kell tekinteni minden olyan mérkőzést, amely az említett kritériumok egyikébe sem sorolható be. Igaz, ez a biztonsági besorolás az UEFA-mérkőzésekre készült, de a

8 2004. évi I. törvény a sportról 
gyakorlat annyira átvitte ezt a szakmai köztudatba, hogy minden sportrendezvény előzetes biztonsági értékelésében ezt a két kategóriát nevesítik.

Az említetten kívül létezik még egy angol kategóriába sorolási rendszer is, amelynek ismerete különösen a nemzetközi kapcsolatok terén juthat jelentőséghez. Ez az angol értékelési lista $\mathrm{A}, \mathrm{B}$ és $\mathrm{C}$ típusú mérkőzéseket különböztet meg, a következő kritériumok szerint:

A kategóriába tartoznak azok a mérkőzések, amelyeken sem a tömeg nagysága, sem a rendbontásra vonatkozó veszély nem tekinthető olyan jelentősnek, hogy az biztonsági problémát okozna.

$B$ kategóriásak azok a mérkőzések, amelyekre a stadion befogadóképességének megfelelő vagy ahhoz közeli tömeg várható, vagy amelyeken különlegesen nagy ellenfél-támogatás lehetséges, de a rendbontás veszélyét kevésbé jelentősnek ítélik meg.

$C$ kategóriába sorolják azokat a mérkőzéseket, amelyekre nagy tömegeket várnak, és amelyek közbiztonságra gyakorolt veszélyessége számottevő.

Az iménti értékelési lista jól láthatóan nagyobb szabadságot ad a biztonságért felelős személyeknek az elózetes értékelésben és a biztonsági kockázatok megítélésében. Feltételezhető, hogy a további szakmai vizsgálatok az UEFA-kritériumok, illetve az angol rendszer valamilyen formájú komplex alkalmazását tartják a jövőben célszerünek.

\section{A szurkolók kategóriái}

A labdarúgó-mérkőzések közönsége által tanúsított magatartás, az elkövetett rendbontások szükségessé tették a szurkolók tanulmányozását és a mérkőzésekhez hasonlóan biztonsági kategóriába sorolását.

A nézők nyolcvanöt-kilencven százaléka érdekes mérkőzést szeretne látni, és élvezni a stadion légkörét. Nagyjából harmaduk a csapathoz való kötődését az egyesület színeit mutató sapkákkal, pólókkal vagy dzsekikkel jelzi.

Ök még alkoholos állapotban is mentesek az erőszakos cselekményektöl. Ezek a szurkolók biztonsági szempontból az A kategóriába tartoznak, és semmilyen problémát nem jelentenek a rendőrség számára.

A $B$ kategóriába tartozó szurkolók szintén a futball megszállottjai, részben a csapatuk fanatikus kísérôi. A magatartásmódjuk fơként érzelemtől befolyásolt. Egy kétséges bírói döntés vagy a „saját” játékos elleni szabálytalanság agressziónövelő hatással van rájuk. A túlzott alkoholos befolyásoltság ennél a csoportnál - amelyet kb. a nézök nyolc-tíz százalékára becsülnek- 
nagy szerepet játszik, mert felerősíti az érzelmeket, és csökkenti az erőszakra való hajlam gátlási küszöbét. Ebben a túlfütött érzelmi fázisban okoznak gondot a rendőrségnek. Tárgyakat dobálnak a játéktérre, fáklyákat gyújtanak vagy rakétákat lőnek ki, és újra meg újra megpróbálják megrohamozni a pályát. Provokálnak és keresik a konfliktushelyzeteket. Ha a rendőrség fellép, számítani kell súlyos sértegetésekre és masszív ellenállásra. Körükben „becsületbeli ügy" egy elfogott szurkolótársat a rendőri őrizetből kiszabadítani.

A B kategóriába tartozó szurkolók többsége tizenöt és harminc év közötti. Gyakran jellemzi őket gazdasági, szociális vagy pszichikai bizonytalanság, nincs jövőre vonatkozó perspektívájuk, és hiányzik nekik a társadalom elismertsége. Csak a velük hasonlók csoportjában számíthatnak elismerésre, és élvezik az erősség érzését. A csoporthoz tartozás jeleként ők is szívesen viselik a szokásos szurkolókellékeket.

A C kategóriába tartozó személyeket gyakorlatilag már nem lehet futballszurkolónak nevezni. Büszkén hívják magukat „huligánnak”, és a mérkőzést kizárólag arra használják fel, hogy erőszakos cselekményeket kövessenek el. Maga a játék nem érdekli őket, az ellenfél azonos felfogású személyeivel keresik a harcot. A rendőrségi vizsgálatok általában azt állapították meg, hogy az ellentétes huligánbandák „tárgyalói” konspiratív módon találkoznak, hogy megbeszéljék a következö összecsapás helyét, idejét és módját. Ha hiányzik a megfelelö ellenfél, az agressziójukat gyakran kívülállókra vagy a rendőrségre irányítják. Ha megerősített rendőri biztosítás van egy stadionban, akkor a huligánok az aktivitásukat a játék előtti vagy utáni időre teszik át. Megvetik a gyávát és csodálják az erőset. Ez érvényes a rendőrségre is. Az ő értelmezésük szerint annak van tekintélye, aki az erőszak alkalmazásában túltesz rajtuk.

\section{A rendőri szerv vezetőjének feladatai}

A rendezvények rendjének fenntartásában közremüködő, területileg illetékes rendőri szerv vezetőjének folyamatos kapcsolatot kell tartania az illetékességi területén lévő sportlétesítmények üzemeltetőivel. ${ }^{9}$ Részt vesz az időszakos pályabejárásokon, biztonságtechnikai szemléken, javaslatokat tesz a biztonsági berendezések fejlesztésére, az átalakítások, korszerüsítések során a biz-

9 Uo. 
tonsági szempontok figyelembevételére. A sportlétesítmény üzemeltetőjével írásbeli megállapodás keretében gondoskodik arról, hogy

- a rendőri biztosítás parancsnoka és törzse számára a létesítmény egészének belátását lehetővé tevő, vezetési pontnak (figyelőpont) alkalmas helyiség és elóállító hely álljon rendelkezésre;

- biztosított legyen a rendörségi technikai eszközök védett elhelyezése;

- a létesítmény hangosító berendezését a biztosítás parancsnoka szükség esetén azonnal és közvetlenül igénybe vehesse;

- a képrögzítő technikai eszközök telepítése, illetve a létesítmény tulajdonában lévő, beépített, zárt láncú televízióberendezések korlátozás nélküli igénybevétele biztosított legyen;

- álljanak rendelkezésre a létesítmény alaprajzára, főbb müszaki paramétereire, biztonsági berendezettségére, tüzvédelmére vonatkozó adatok.

A sportegyesületek vezetöivel időszakonként, különösen a bajnokságok, mérkőzéssorozatok kezdetekor és annak befejezésekor értékeli a mérkőzések, találkozók lebonyolításának közbiztonsági hatásait, tapasztalatait. Javaslatot tesz a közbiztonság érdekében szükséges kölcsönös kapcsolatok bővítésére. Felvilágosító propagandamunkával bekapcsolódik a szurkolói klubok, baráti körök rendezvényeibe, törekszik arra, hogy a biztonság, a rendezvények rendjének fenntartása közös érdekként jelenjen meg a találkozókon.

A rendőri szerv vezetőjének feladatkörébe tartozik a szurkolók nézőtéri és pályán kívüli magatartásának figyelemmel kísérése, a jogsértőkröl, rendbontókról rendelkezésre álló adatok folyamatos gyüjtése, értékelése, illetve ezeknek a feladatoknak a rendőri szerven belüli elosztása. Gondoskodik arról, hogy a szervezetten utazó szurkolókat a hazai és a nemzetközi mérkőzésekre az erre a feladatra kijelölt rendőr (rendörök) elkísérje. A rendbontókról rendelkezésre álló adatokat megosztja a biztosítást végrehajtó rendőri szervekkel.

\section{A rendezvénybiztosítás előkészítése}

A rendezvény biztosításával kapcsolatos rendőri tevékenység két fô részből, az előkészítési és a végrehajtási szakaszból áll. Az előkészítés a tervezés és a szervezés feladatait foglalja magában. A tervezés időszaka a konkrét rendezvényhez kötődő adatok értékelésétől (az elöljárótól kapott feladat tisztázásától) a tervokmányok kidolgozásáig, a szervezés időszaka az alárendeltek feladatainak meghatározásától a készenlét eléréséig tart. Természetesen az előkészités két 
időszakát egymástól élesen elhatárolni nem lehet, azok a biztosítás előkészítése során egymást átfedhetik. A sportrendezvények kiemelt rendőri biztosításának végrehajtását illetékességi területére kiterjedően a rendőrfőkapitány (helyettesei) írásos intézkedésben rendelheti el, amelynek tartalmaznia kell

- a sportrendezvény megnevezését, helyét, idejét;

- a közbiztonságra gyakorolt várható hatásának megítélését;

- a biztosító szolgálat tevékenységi körzetét;

- a biztonság érdekében alkalmazható intézkedések, így különösen a fokozott ellenőrzés, a ruházat, csomag és jármü átvizsgálása, területlezárás, a forgalomszabályozás, a szervező segítségének igénybevétele, a közterület frekventált helyeinek és a tömegközlekedési eszközök utasforgalmának ellenörzése, a közterület rendjének fenntartása követelményeit;

- a rendőri erök magatartásának általános szabályait jogsértés és tömeges rendbontás esetén;

- a sportrendezvényt megelőző és az azt követő sajtókezelés és a tömegtájékoztatás feladatait;

- a biztosításba bevont állomány eligazításának szempontjait;

- a biztosítás parancsnokát és helyettesét;

- a rendbiztost (amennyiben külön szükséges);

- a biztosító szolgálatra igénybe vehető személyi állományt és technikai eszközöket, a megerösítő erők igénylésének rendjét;

- a biztosító szolgálatra történő áttéréshez szükséges szervezési feladatokat;

- a jelentések rendjét.

Ha a rendőri szerv illetékességi területén előre kiadott időpontokban ismétlődnek a sportrendezvények (például bajnokságok, kupamérkőzések stb.), a biztosítást elrendelő vezető egy intézkedésben is meghatározhatja a fő feladatokat az adott időszakra, idényre, bajnokságra. Ha a rendőri szerv vezetője a sportlétesítmény meghatározott területére fokozott ellenőrzés végrehajtását rendeli el, az egyes részfeladatok ellátására (ruházat-, csomag-, jármüátvizsgálás, értesítés, visszatartás) a rendező szervet hivatalosan felkérheti. A felkérés alapján közremüködőket a feladatokra előzetesen fel kell készíteni, tevékenységüket rendőri erővel biztosítani kell.

A rendőri szerv vezetője által kijelölt biztosítás parancsnoka ${ }^{10}$ a továbbiakban személyesen felelős a rendőri feladatok előkészítéséért és végrehajtásáért.

10 Csapatszolgálati Szabályzat. 11/1998. ORFK Utasítás. 
Parancsnoki munkájának legelső eleme az elöljárótól kapott feladat tisztázása. Ennek során meg kell értenie:

- az előtte álló biztosítási feladat célját;

- a rendőrfőkkapitánynak a sportrendezvény biztosítására vonatkozó alapintézkedésében meghatározott általános feladatok érvényesítésének módját;

- a konkrét biztosítás érdekében a számára meghatározott feladat tartalmát.

A parancsnoknak tisztáznia kell, hogy

- milyen rendőri erőket és eszközöket vehet igénybe, azok mikor kerülnek az alárendeltségébe, illetve meddig állnak a rendelkezésére;

- a szomszédos rendőri szervek a rendezvény időszakában milyen tevékenységet folytatnak, milyen feladatokat oldanak meg az érdekében (például járművek kísérése, útvonalak, tömegközlekedési eszközök ellenőrzése, információgyüjtés a létszámról, összetételről stb.);

- kivel, mikor, hogyan kell együttmüködnie;

- az elöljáró rendőri szerv vezetője milyen feladatok végrehajtását tartja meg a saját kezében (például bünügyi adatgyűjtés, korábbi jogsértések elkövetőinek felderítése a szurkolók között stb.), illetve milyen feladatokra készít fel további rendőri erőket (például központi tartalék képzése stb.);

- mekkora területre terjed ki a biztosítás felelösségi körzete;

- mennyi idő áll a rendelkezésére, mikor kell a készenlétet elérnie (időszámvetés elvégzése);

- illetékességi területén az egyéb szolgálatok fenntartására milyen lehetőségei vannak, azt hogyan tudja megoldani.

A feladattisztázásból levont következtetések alapján a biztosítás parancsnoka már előzetes intézkedést tud kiadni alárendeltjeinek annak érdekében, hogy mielőbb megkezdhessék a felkészülést. Elözetes intézkedésében a parancsnok már tájékoztatást ad a feladatról, az alárendelt várható feladatának jellegéről, meghatározza a folyamatban lévő feladatok befejezésének vagy módosításának rendjét, gondoskodik a személyi állomány, az anyagi-technikai eszközök szükséges összevonásának, átcsoportosításának elökészítéséröl.

A tervezés időszakának következő eleme a helyzetértékelés végrehajtása, amelynek tartalmát a küszöbönálló tevékenység körülményeinek mindenoldalú tanulmányozása, értékelése és azokból a következtetések levonása adja. Ezen belül a közbiztonsági helyzet vizsgálatakor ki kell térni arra, hogy

- a rendezvényre milyen létszámú közönség várható, milyen az összetétele, várhatóan hogyan alakul a „hazai” és a vendégszurkolók aránya; 
- a vendégszurkolók szervezetten (például különvonattal, külön autóbuszokkal, menetrend szerinti járatokon stb.) vagy egyénileg utaznak-e a mérközés helyszínére;

- milyen a két vagy több szurkolótábor viszonya egymással, történt-e korábbi mérkőzéseken közöttük konfrontáció és milyen formában;

- mi jellemzi az adott szurkolótábor tagjai által elkövetett jogsértő magatartásokat, mennyiben alkalmazkodnak a helyszín belső rendjéhez, milyen a viszonyuk a rendezőkkel, a rendörséggel;

- a rendezvényt előtt, közben illetve utána mikor várhatók a legkritikusabb időszakok, milyen megnyilvánulásokra lehet számítani;

- milyen létszámú a rendezői gárda, milyen a kor és nem szerinti összetétele, a korábbi tapasztalatok alapján mennyire képes fenntartani a belső rendet, érvényt szerezni a biztonsági rendszabályoknak;

- az adott városban, településen, városrészen általában milyen büncselekmények fordulnak elő, milyen változásokra lehet számítani a sportesemény alatt;

- a hazai és a vendégszurkolók, valamint az egyéb közremüködők biztonságát milyen körülmények veszélyeztetik, mekkora kockázattal jár a mozgásuk a megközelítési útvonalakon, a létesítmény közvetlen körzetében és azon belül.

A saját rendőri erők értékelésekor szükséges megvizsgálni:

- rendelkezésre áll-e a szükséges létszám vagy az elöljáró rendőri szerv vezetöjétöl, illetve az együttmüködőktől kell megerősítést igényelni;

- milyen az állomány összetétele, kiképzettsége, milyen szolgálati tapasztalata van a sportrendezvények biztosításában;

- milyen a rendörök fizikai állapota, hogyan képesek elviselni a tömeggel kapcsolatos pszichikai hatásokat;

- az anyagi, technikai eszközök elégségesek-e a feladat végrehajtásához, vagy összevonásra, átcsoportosításra kell intézkedni az elöljáró útján;

- a parancsnoki kar milyen felkészültséggel, vezetési tapasztalatokkal bír;

- hogyan oldható meg az állomány elhelyezése, szállítása, élelmezése, pihentetése;

- a rendelkezésre álló erőkkel biztosítható-e a rendezvényen kívüli alapszolgálatok elégséges szintü fenntartása.

A szomszédos rendőri szervek helyzetének tanulmányozásakor a biztosítás parancsnoka megvizsgálja, hogy 
- a szomszédos és a távolabbi rendőrkapitányságok és a központi rendőri szervek kijelölt állománya hogyan kapcsolódik be a szurkolók utazásainak rendőri ellenőrzésébe a közutakon, a vonatokon, a vasútállomásokon, más közlekedési csomópontokon, az útvonalakon milyen létesítmények biztosítását helyezték elötérbe;

- kísérik-e a szurkolókat polgári ruhás rendőrök;

- hogyan valósítható meg a leggyorsabban és a legpontosabban egymás kölcsönös tájékoztatása;

- milyen lehetőség van és milyen formában a váratlan események hatékony rendőri kezelése érdekében a kölcsönös segítségnyújtásra.

A biztosításparancsnoki helyzetértékelés egyik legfontosabb eleme a környezet, a létesítmény tanulmányozása. Ezen belül pontosítani kell:

- milyen a helyszín állaga, befogadóképessége, szektorainak száma, álló- és ülőhelyeinek aránya, a kijáratok elhelyezkedése;

- vannak-e a létesítményben a nemzetközi elöírásoknak megfelelö biztonsági berendezések;

- mennyire biztosított a szurkolótáborok elválasztása a helyszínen belül, azon kívül és a megközelítési (távozási) útvonalakon;

- milyen lehetőségek vannak a tömeg menekítésére, a rendbontó személyek kiemelésére, a szektorok részleges vagy teljes kiürítésére;

- vannak-e balesetveszélyes tereptárgyak (például építési terület, állványzat, törmelék stb.) a biztosítás körzetében, milyen lehetőségek vannak ezek elkerítésére vagy eltávolítására;

- merre vezetnek a tömeg fö mozgási irányai a közterületen, hol helyezkednek el italboltok, szórakozóhelyek, középületek stb., mit kell tenni ezek biztonsága érdekében;

- milyen a biztosítás körzetében a közlekedési hálózat, mennyiben járul hozzá - különösen a rendezvény befejezése után - a közönség gyors eltávozásának elősegítéséhez, milyen forgalomszervezési intézkedések szükségesek (például útlezárás, forgalomirányítás, tömegközlekedési járatok sürítése stb.);

- hol helyezkednek el vízvételi lehetőségek (tüzoltók, rendőrségi vízágyúk részére), hol húzódnak nagyfeszültségü légvezetékek;

- hol húzódnak a rendőrség, a mentők, a tüzoltók mozgásához alkalmas manőverezési útvonalak, milyen intézkedéseket kell tenni ezek szabadon tartása érdekében. 
A rendezvény körzetében élő lakosság értékelésekor meg kell ítélni, milyen a viszonyuk a sportesemények lebonyolításakor kialakuló, fokozott kockázatot jelentő közbiztonsági helyzethez, a bevezetendő rendőrségi és más hatósági intézkedésekhez, segítik-e ezeket vagy kedvezőtlenül fogadják. Várható-e konfrontáció a szurkolók és a lakosság között, mit kell tenni ennek megelőzésére. Milyen mértékben kell tájékoztatni a lakosságot az elsősorban a vagyonbiztonságuk megóvása érdekében szükséges rendszabályokról.

A napszak, az évszak és az időjárás értékeléséből következtetéseket lehet levonni az alárendeltek felkészítésének rendjére, a szükséges felszerelésre és az öltözetre, a pihentetésre, a személyi állománynak a meleg vagy a hideg időjárás hatásaitól való megóvására, az utak járhatóságára, a tömegközlekedés helyzetére stb.

A rendőri biztosítás parancsnoka rendezvény előtt köteles

- felvenni a kapcsolatot a rendezvény szervezőivel, részt venni a szervezö, a sportegyesületek, a sportlétesítmény üzemeltetői által szervezett egyeztető értekezleten;

- tájékozódni, hogy a szervezők a biztonság és a rend fenntartása érdekében milyen intézkedéseket tettek, illetve terveznek;

- egyeztetni a szervezőkkel a rendőrség és a rendezők közötti együttműködés, a kapcsolattartás és az értesítés formáit;

- részt venni az előzetes létesítménybejáráson.

A szervező, a rendező, a sportlétesítmény üzemeltetője, a sportegyesületek, a rendőrség és a biztonságban érdekelt más szervek részvételével lebonyolított előzetes egyeztető értekezleten a biztosítás parancsnoka felhívja a figyelmet a következőkre:

- a rendezvény, valamint a sportlétesítmény rendjét, a közönségtől a szervező által elvárt magatartási szabályokat a jegyek hátoldalán tüntessék fel, a létesítmény, valamint szektorok bejáratainál függesszék ki, vagy gondoskodjanak ezeknek a nézőkhöz szórólapokon történő eljuttatásáról;

- a sportlétesítmény előzetes biztonsági átvizsgálására, az elrejtett közbiztonságra különösen veszélyes és más eszközök felkutatására, a létesítmény örzésére;

- a belépéskor a biztonsági ellenőrzés alaposságára;

- a nézőktől elvett, a biztonságra veszélyt jelentő, de a rendezvény végén visszaadható tárgyak kezelésére;

- a szurkolók biztonságos elkülönítése érdekében szükséges intézkedésekre;

- parkolóhelyek kijelölésére; 
- a tömegkiszolgálás érdekében teendő intézkedésekre, így különösen az elsősegélyhelyek, illemhelyek, vízvételi lehetőségek, büfék telepítésére, a tömegközlekedési vállalatok értesítésére;

- a személyeket és anyagi javakat közvetlenül fenyegető veszélyhelyzet kialakulásának megelőzésére;

- a szeszes ital árusításának megtiltására;

- a rend fenntartása érdekében alkalmazott rendezők által jól felismerhető megkülönböztető jelzés, így formaruha, rendezői mellény, egyensapka, vagy karszalag viselésének fontosságára;

- a nézők folyamatos tájékoztatására, felvilágosításadására;

- a pályára nyíló menekülőkapuk és vészkijáratok lezárásának tilalmára, ezek rendezőkkel történő biztosítására.

Az egyeztető értekezleten elhangzottakat jegyzőkönyvben kell rögzíteni, amelyet valamennyi érdekelt aláír. Jegyzőkönyv felvételének elmaradása esetén az értekezletröl hivatalos rendőrségi feljegyzés készül.

Arra a sportlétesítményre, amelyben rendszeresen kerül sor biztosító szolgálatra, állandó biztosítási terv is készíthető. A biztosítási tervet az adott alkalomra a rendőri szerv vezetője a feladatot elrendelő intézkedésével lépteti érvénybe. A kisebb (például létszám, eszköz, vezénylési hely, idő, öltözet, felszerelés) változásokat eseti tervkiegészítésben kell rögzíteni. A rendőri biztosítás elgondolását érintő változás (például szolgálati csoportok számának növelése, csökkentése, a tevékenység körzeteinek, irányainak, a feladatok tartalmának módosítása stb.) esetén új biztosítási tervet kell kidolgozni.

A kiemelt biztosításra kijelölt parancsnoki állomány részére a biztosítás parancsnoka a jóváhagyott biztosítási terv alapján, a feladat megkezdése előtt a helyszínen szemrevételezés keretében tart részletes eligazítást. Ennek során pontosítani kell az egyes szolgálati csoportok elhelyezkedését, működését, működési körzetük kiterjedését, az együttmüködés, a segítségnyújtás, az öszszevonás és átcsoportosítás rendjét, a tájékozódás érdekében kijelölt tereppontokat. A jogsértések esetére tervezett beavatkozások egy-egy mozzanatát parancsnoki foglalkozás keretében modellezni kell.

A feladatba bevont teljes személyi állomány felkészítésére közvetlenül a feladat előtt, a készenléti idő eléréséig kerül sor. A feladatok és szolgálat ütemezésétől függően az eligazításra eltérő időpontokban, szolgálati csoportok vagy csoportosítások szerint is sor kerülhet. A felkészítés és eligazítás rendjét a biztosítás parancsnoka a biztosítási tervben szabályozza. A jóváhagyott 
biztosítási tervben a feladat megkezdéséig módosításokra, kiegészítésekre csak a jóváhagyó vezető engedélyével, írásban kerülhet sor.

„A rendészet a közigazgatáson belül fejti ki hatását, a rendészet fogalmának centrumában a közbiztonság védelme áll. A belsö rend védelme nemzetbiztonsági feladat. A közrend kategóriája független a rendészettöl." ${ }^{\prime l}$

\section{A törzs}

A rendőrség szolgálati munkájában kiemelt jelentősége van az összetett rendőri müveletek vezetésének, ezek előkészítése és végrehajtása a rendőri szervek vezető és beosztott állományától magas fokú szakmai ismereteket, hozzáértést és tervszerüséget igényel. Az Országos Rendőr-fökapitányságon, a rendőr-fökapitányságokon és központi alárendeltségben lévő más területi rendőri szerveknél létre kell hozni a csapaterő vezetésének szerveit ${ }^{12}$, ki kell jelölni állományát, és ki kell dolgozni a részletes munkarendjét.

A törzs az Országos Rendőr-fökapitányságon, a rendőr-főkkapitányságokon, a Készenléti Rendőrségnél a rendőri műveletek vezetésének alapvető szerve. Ideiglenesen müködtetett szervezeti elem, amely közvetlenül részt vesz az alárendeltek feladatainak megtervezésében, a végrehajtás szervezésében és irányításában.

A megyei rendőr-főkapitányságokon a törzs vezetője a közrendvédelmi és határrendészeti osztályvezető, a Budapesti Rendőr-fökapitányságon a közrendvédelmi főosztályvezetö. Az országos törzs vezetője teljes feltöltöttség esetén az ORFK közrendvédelmi főkapitány-helyettese.

A törzs közbiztonsági, bűnügyi, híradó, anyagi, technikai, egészségügyi és összekötő-futár csoportokból áll. Az országos törzsben szükség esetén külön személy- és létesítménybiztosítási csoport is müködhet.

A közbiztonsági csoport rendeltetése a közbiztonsági helyzet elemzése, értékelése, a következtetések alapján javaslatok kimunkálása a feladat megoldására irányuló döntéshez. A kidolgozott intézkedéseknek a végrehajtók részére történő eljuttatása, a helyzet adatainak gyüjtése, számvetések kidolgozása, a szomszédos és együttmüködő szervek tájékoztatása, a rendőrfőkkapitány szóban kiadott utasításainak, parancsainak rögzítése, az elhatározás előkészítése és formába öntése. Parancsnoki intézkedések kidolgozása, az együttmüködés

11 Balla Zoltán: i. m.

12 17/2010. ORFK Utasítás a törzs működéséről. 
megszervezésének előkészítése, a csapatfelderítés és az álcázás rendszabályainak kidolgozása, a rejtett vezetést szolgáló okmányok kidolgozásának irányítása, a vezetési pont telepítésének, áttelepítésének, örzésének és védelmének a megtervezése. Az ügyeleti szolgálat megszervezése a törzsben és a vezetési ponton, az elöljáró számára szóló jelentések összeállítása, az eseménynapló és a nyilvántartó térkép vezetése, az alárendeltek ellenőrzésének és a tevékenységekhez való felkészülésük segítésének a megszervezése.

A bünügyi csoport feladata a döntéshez szükséges bünügyi információk beszerzésének megtervezése, megszervezése, a bünügyi szervek tevékenységének irányítása, a felderítési feladatok, nyomozási cselekmények összehangolása, a beérkező adatok feldolgozása és továbbítása a törzs vezetőjének, illetve a rendőrfő́kapitánynak.

A híradó- és informatikai csoport feladata a híradás megtervezése, a híradó és informatikai rendszer üzemkészségének fenntartása, a vezetési pontok települési helyeinek állandó ismerete. Az alárendelteknek szóló híradó intézkedések, tervek, okmányok kidolgozása és eljuttatása, a hírrendszer telepítésének irányítása, a híradó eszközökön folytatott párbeszédek szabályainak és a híradó-üzemfegyelem rendszabályainak megkövetelése és ellenőrzése. A rádióelektronikai védelem rendszabályainak a kidolgozása, a törzs állományának kiképzése a technikai eszközök kezelésére, a rejtett vezetést szolgáló okmányok alkalmazására, az alárendeltek híradó eszközökkel történő ellátásának biztosítása, azok üzemeltetésének és nyilvántartásának megszervezése, a csapattevékenység informatikai biztosítása.

Az anyagi, technikai, egészségügyi csoport feladata a tevékenység mindenoldalú biztosításának részeként az anyagi ellátás, a technikai eszközök kiszolgálásának és a személyi állomány egészségügyi ellátásának megtervezése, megszervezése. Az anyagi, technikai, egészségügyi biztosítás tervének kidolgozása és az abban foglalt feladatoknak az alárendeltekhez történő eljuttatása, a vezetési pont településének, áttelepülésének, anyagi kiszolgálásának közvetlen irányítása.

Az összekötő-futár csoport létrehozására a feladat jellegétől függően, szükség szerint kerül sor. Feladata a rendőrfökapitány, a törzs, valamint az elöljáró és az alárendelt szervek között a parancsok, intézkedések, jelentések továbbítása, a küldemények kézbesítése, az együttmüködő szervekkel a folyamatos kapcsolat fenntartása, javaslattétel a közös feladatok pontosítására, összehangolására, a megerősítő szervek alkalmazásának módjára.

A személy- és létesítménybiztosítási csoport feladata a védett vezetők, delegációk és objektumok biztonságára vonatkozó adatok gyüjtése, elemzése, 
értékelése, az általános veszélyeztetettségi szint meghatározása, a biztonság megteremtése és fenntartása érdekében szükséges szolgálati követelmények meghatározása. A megelőző, a személy- és objektumvédelmi állomány tevékenységének megtervezése, az erre vonatkozó szolgálati okmányok kidolgozása, a szolgálati ágak közötti koordináció végrehajtása. Kapcsolattartás és koordináció az érintett külső szervekkel, javaslattétel a szolgálati feladatok személy- és létesítménybiztosítási teendőire.

A közbiztonsági csoport három-öt, a többi csoport két-három fös lehet. Ettől a rendőrfőkapitány a feladatok jellegétől függően eltérhet, a csoportok létszámát növelheti.

\section{A vezetési pont}

A vezetési pont ${ }^{13}$ az a meghatározott kiterjedésü, technikai és más eszközökkel berendezett terület, amely a feladatok előkészítése és végrehajtása időszakában egyaránt megteremti a vezető szervek (személyek) folyamatos müködéséhez szükséges feltételeket, lehetővé teszi az alárendeltek tevékenységének közvetlen irányítását. A vezetési pont általában rendőrségi vagy más objektumban, szükség esetén a terepen hozható létre. A vezetési pont vezetési csoportra, hirközpontra és biztositó csoportra tagolódik.

A vezetési csoport a vezetési pont alapvető eleme, amely a parancsnokból, a tanácsadó testületből (operatív bizottság), valamint a törzsből áll. Rendeltetése a különböző munkahelyen lévő szolgálati személyek összehangolt, tervszerü munkájával az elhatározás megalkotása, a döntések meghozatala, a törzsszolgálati feladatok ellátása, az alárendelt szervek vezetése.

A híradóközpont rendeltetése a folyamatos és megbízható összeköttetés fenntartása a vezetési ponton belül az elöljáróval, az alárendeltekkel és az együttműködő szervekkel. A híradó és informatikai eszközöket és azok kezelỏállományát foglalja magában.

A biztosítócsoport rendeltetése a vezetési pont személyi állománya munkájához, pihenéséhez, ellátásához a megfelelő feltételek megteremtése, a vezetési pont őrzése. Állományába örség, szállító részleg és ellátó részleg tartozik. A biztosítócsoport általában a vezetési csoporttól elkülönítve helyezkedik el.

Lakossági tájékoztató, információs szolgálat müködhet a biztosítás vezetési pontján. Feladata külön városi telefonszámok megadása a tömegkommuni-

13 Uo. 
káció részére, ahová bármilyen felvilágosításért lehet fordulni. A tájékoztató szolgálat folyamatos kapcsolatot tart a biztosítás rendvédelmi szervei, illetve a tömegkiszolgálásban részt vevő más szervek (mentő, tömegközlekedés, kommunális létesítmények, egészségügyi létesítmények stb.) ügyeleteivel.

A vezetési pont létrehozásának (településének) helyét és idejét a parancsnok határozza meg. Helyét csak azok ismerhetik, akiknek szolgálati feladataik ellátásához az feltétlenül szükséges. A vezetési pont megszervezéséért a törzs vezetője a felelős, aki meghatározza a vezetési pont állományát, a munkavégzés, az ügyeleti szolgálat ellátásának, pihentetésének a rendjét, a vezetési pont őrzés-védelmével kapcsolatos rendszabályokat és szükség esetén az áttelepülés feladatait.

A vezetési pont helyének pontos kijelölése és annak berendezése érdekében elökészítő részleg kijelölésére kerülhet sor. Az elökészítő részleg vezetőjének meg kell határoznia:

- a vezetési pont létesítésének helyét;

- a berendezéssel kapcsolatos feladatokat, követelményeket;

- a híradást milyen rendszerben kell kiépíteni;

- az örzés szabályait;

- a végrehajtás határidejét;

- az előkészítő részlegbe beosztott erőket és eszközöket.

Szükség esetén gondoskodni kell a vezetési pont álcázásáról és a polgári személyektől (a lakosságtól) történő elszigeteléséröl. A vezetési pont körzetében szabályozni kell a személyi állomány és a szállítóeszközök mozgásának rendjét. A vezetési ponton tartalék alegység, elöállító hely, sajtóközpont nem helyezhető el.

A vezetési pont örzésére és védelmére tervet kell készíteni, amely szöveges, rajzos és táblázatos formában tartalmazza:

- a vezetési pont elemeinek elhelyezkedését;

- az őrzendő objektumokat, az őrzésre kijelölt erőket;

- az őrök felállítási helyét, a járőrök menetvonalait, feladataikat;

- a tüzelóállásokat;

- a riasztás, értesítés rendjét, jeleit, jelzéseit;

- az áttelepüléssel kapcsolatos feladatokat és az egyéb szükséges rendszabályokat.

A rendőri müvelet körzetén belül, a fö feladat végrehajtásának körzetében a parancsnoknak figyelöpont is berendezhetö. A figyelöpont rendeltetése a fö 
feladatot végrehajtó alárendeltek tevékenységének közvetlen megfigyelése és azok vezetése a végrehajtás legfontosabb időszakában. A vezetési pont állományából a figyelőponton csak a legszükségesebb szolgálati személyek tartózkodhatnak. Amikor a parancsnok a figyelőponton van, a helyettesének minden esetben a vezetési ponton kell tartózkodnia. A vezetési pont mellett, attól legfeljebb két kilométernyire helikopter-leszállóhely is kijelölhetö. A helikopter-leszállóhely őrzéséről külön gondoskodni kell.

\section{Új típusú kommunikációs platformok}

„Csak az tud biztonságot szolgáltatni, aki maga is biztonságban él." ${ }_{14}$ Az elmúlt évtizedekben kiemelt figyelmet kapott a különböző rendezvények biztosításának végrehajtása, valamint a biztonság kérdése. A kilencvenes évek elötti időszakban ritkán kellett komoly és összetett rendőri vezetést igénylő feladatokat végrehajtani, de a kilencvenes évek közepétől egészen 2006-ig több fontos eseményt kellett biztosítani, ez kialakított egyfajta vezetési stílust és módszert (például: pápalátogatások, nemzetközi sportesemények stb.).

A 2006-ban történt események rávilágítottak a rendőri tevékenységirányítás szervezeti-szervezési, vezetési és technikai hiányosságaira, ezért szükségessé vált a vezetés rendjének új alapokra helyezése, valamint a technikai és szervezeti fejlesztések az új típusú kihívásoknak való megfelelés érdekében.

A jelenleg működő szervezeti rend és technikaiháttér-támogatottság már nem felel meg minden tekintetben a huszonegyedik század követelményeinek, ezért szükségessé vált egy újfajta, átgondoltabb, új alapokon nyugvó rendszer kialakítása. Ehhez a korábbi alapok és a bázis megfelelő, de újfajta rendszerek, eljárások és lehetőségek bevezetésével a kor színvonalának megfelelö helyzetbe hozhatók azok az egységek és vezetöik, amelyek, illetve akik felelnek a rendezvények biztonságáért és biztosításáért, így a tevékenységirányítás korszerüsödhet.

A tevékenységirányítás új, a korábbi években ritkán használt elemei kerültek előtérbe 2006 októbere után, amikor Budapest közterületein a jelentős tömegrendezvényeken, tüntetéseken tömegoszlatás történt. Az akciócsoportok parancsnokainak kezdetben kis tapasztalatuk volt, a tömegoszlatási fel-

14 Salgó László: A magyar rendörség jelene, jövője, kilátásai. Magyar Kriminológiai Társaság, Budapest, 2004 [Kriminológiai Közlemények 61.] 
adatokban gyakorlatlanok voltak, több esetben pedig kommunikációs nehézségek léptek fel az akciócsoport-parancsnokok és a tevékenységüket irányító bevetésirányítási központ között.

\section{A WiMAX technológia alkalmazhatóságának alapjai}

Az új típusú tevékenységirányítás rendszeréhez olyan környezeti eszközökkel biztosított kommunikációs rendszerre van szükség, amely javítja a kiemelten kezelendő problémákat és a kommunikáció egyéb követelményeit is. Erre dolgoztam ki megoldási javaslataimat is, amelyeket e fejezetben kívánok bemutatni. A rendszer összeállítását, jellemzőinek megfogalmazását a Zrínyi Miklós Nemzetvédelmi Egyetem híradó tanszékének 2008 és 2010 között végzett tesztsorozati tapasztalatai alapján állítottam össze.

A WiMAX ${ }^{15}$ gyökerei az informatika, azon belül is a hálózatok robbanásszerü fejlődéséhez nyúlnak vissza. A személyi számítógépek széles körü megjelenése az otthonokban is, valamint az internet mint információs, szórakoztató és nem utolsósorban munkaeszköz egyre elterjedtebb használata rendre nagyobb és nagyobb adatforgalmat von maga után. Az ezredforduló után a fordulópontot a széles sávú internet-hozzáférés (DSL, kábel stb.) jelentette, ez felváltotta az addigra elavult modemes technológiát.

A mobiltelefonok tömeges elterjedésével egy időben ugrásszerủen megnőtt a hordozható, kisméretü eszközök (laptop, $\mathrm{PDA}^{16}$ stb.) iránti kereslet - a kulcsszó a mobilitás lett. A megoldást egy vezeték nélküli, de a már meglévő hálózatokkal teljes mértékig kompatibilis hozzáférés jelentette. A TCP ${ }^{17} / \mathrm{IP}^{18}$ protokoll felhasználásával, az Ethernet „továbbfejlesztésével” megszületett az IEEE ${ }^{19} 802.11$-es szabvány - közismertebb nevén wifi ${ }^{20}$-, vagyis az első WLAN $^{21}$.

A wifi alkalmas a vezetékes helyi hálózatok (LAN) kiváltására, de nem alkalmas nagy távolságú kapcsolatra, sem pedig egy gyalogos sebességénél gyorsabban mozgó eszközök kiszolgálására. Továbbra is megmaradt tehát az igény a széles sávú, közepes távolságú vezeték nélküli hozzáférésre. A tele-

\footnotetext{
15 World wide Interoperability for Microwave Access (világméretű együttműködés a mikrohullámú hozzáférésért)

16 Personal Digital Assistent (személyi digitális asszisztens)

17 Transfer Control Protocol (átvitelvezérlő protokoll)

18 Internet Protocol (internetprotokoll)

19 Institute of Electrical and Electronics Engineers (villamosmérnökök intézete)

20 Wireless Fidelity

21 Wireless Local Area Network (vezeték nélküli helyi hálózat)
} 
kommunikáció és az informatika konvergenciája révén, a sávszélesség és a mobilitás iránti megnövekedett igény következtében szükségessé vált egy új, széles sávú, közepes távolságú mobiladat-átviteli rendszer. A vezeték nélküli hozzáférési hálózatok sokfélesége arra késztette a világméretü kommunikációs, informatikai nagyvállalatokat, hogy összefogva közös, könnyen elterjeszthető, és elfogadtatható szabványt dolgozzanak ki. A mikrohullámú, vezeték nélküli széles sávú adatátvitel világméretủ egységesítése, elterjesztése érdekében létrehozták a WiMAX Fórumot, amelynek napjainkra már több mint 350 tagja van, szolgáltatók és gyártók egyaránt. Munkacsoportjai különböző ajánlásokat (WiMAX-profilok) dolgoztak ki, olyan átfogó szabvány megalkotása érdekében, amely elősegíti a széles sávú vezeték nélküli hálózatok és technológiák gyors elterjedését.

„A vezeték nélküli mikrohullámú adatátviteli hálózatokkal két szabványositási szervezet is foglalkozik, az IEEE, és a ETSI ${ }^{2}$ különbözö szabványokban. Az IEEE 802.16 és az ETSI HiperMAN ${ }^{23}$ szabványok közös metszete, a 256FFT ${ }^{24}$ OFDM $^{25}$ (opcionális UL ${ }^{26}$, FFT2048 OFDMA ${ }^{27}$ ) technológia a különbözö WiMAX profilok alapja. Az IEEE 802.16 szabályozza az állandóhelyi vezeték nélküli szélessávú kapcsolatok levegö interfész kialakitását. Széles frekvenciasávot támogat (10-66 GHz-ig), változatos csatorna sávszélességek alkalmazásával (1,25 MHz-töl $20 \mathrm{MHz}$-ig), pont-pont összeköttetések megvalósitása esetén. A technológia 2003. évi 802.16a jelü módositása már tartalmazza az NLOS ${ }^{28}$, illetve PMP ${ }^{29}$ kapcsolatok kialakitásának lehetöségét, mint állandóhelyi szélessávú felhasználói hozzáférést, melyet a 2004. évi, 16d jelü (802.16-2004) átdolgozás egészit ki, és meghatározza a WiMAX rendszer profilokat, a 2-11 GHz-es sávban. A 2005. novemberben elfogadott 802.16e kiegészités a mobil (gyalogos-, illetve gépjármü sebességü) megvalósitást szabályozza a $6 \mathrm{GHz}$ alatti frekvenciatartományban, lehetôvé téve a hordozható felhasználói eszközök vándorlását a szolgáltatási területen belül, illetve között." ${ }_{30}$

\footnotetext{
22 European Telecommunications Standards Institute (Európai Távközlési Szabványintézet)

23 High Performance Radio Metropolitan Area Network (nagy teljesítményű rádiós városi hálózat)

24 Fast Fourier Transform (gyors Fourier-átvitel; tulajdonképpen az OFDM-vivők száma)

25 Orthogonal Frequency Division Multiplexing (ortogonális frekvenciaosztásos multiplexálás)

26 Uplink (adatátviteli irány, felhasználói eszköztől a központi állomás felé)

27 Orthogonal Frequency Division Multiplexing Access (ortogonális frekvenciaosztásos multiplexálási hozzáférés)

28 Non Line of Sight (közvetlen rálátás nélküli)

29 Point to Multipoint (egy bázisállomás-több felhasználói állomás topológia)

30 Vass Zoltán: A WiMAX hálózat jellemzői, gyakorlati alkalmazhatósága a Magyar Honvédség hírrendszerében. Zrínyi Miklós Nemzetvédelmi Egyetem, 2006
} 
A világméretű együttmüködés érdekében külön-külön meghatározták az alkalmazni kívánt frekvenciatartományokat, valamint megjelöltek lehetséges frekvenciákat is, a későbbi bővítésre. Európában, így Magyarországon is a 3,5 GHz-es illetve az 5,8 GHz-es (de lehetséges a 2,3 és a 2,5 GHz) sávok alkalmazhatók, a nemzeti frekvenciagazdálkodási jellegzetességek figyelembevételével. Hazánkban a Nemzeti Hírközlési Hatóság és a Kormányzati Frekvenciagazdálkodási Hatóság szabályozza e sávok használatát. A jelenlegi szabályok alapján a 2,3, a 2,5 és a 3,8 GHz sáv egyediengedélyezés-köteles, míg mentességet csak az 5,8 GHz-es tartomány élvez. (A katonai célokra fenntartott úgynevezett NATO IV sáv, amely névlegesen az $5 \mathrm{GHz}$-es tartomány, ami a valóságban 4,5-5,0 GHz-et jelent, elvi síkon lehetőséget ad külön frekvenciahasználati engedély nélkül eszközök és rendszerek telepítésére és alkalmazására.)

Az átviteli csatorna sávszélessége 1,25 MHz-től $20 \mathrm{MHz}$-ig különböző diszkrét értéket vehet fel. A 802.16-2004 WiMAX profil által ajánlott sávszélességeket és a duplexitás biztosításának módjai az alkalmazott frekvenciasáv függvényében eltérők lehetnek (táblázat).

Adatátvitelisáv-szélesség

\begin{tabular}{|c|c|c|}
\hline Frekvenciasáv (GHz) & Duplexitás & $\begin{array}{c}\text { Csatorna-sávszélesség } \\
(\mathrm{MHz})\end{array}$ \\
\hline 2,5 & TDD $^{31}$ & 5 \\
FDD $^{32}$ & 5 \\
\hline \multirow{2}{*}{3,5} & TDD & 3,5 \\
& & 7 \\
& FDD & 3,5 \\
& & 7 \\
\hline 5,8 & TDD & 10 \\
\hline
\end{tabular}

A mobil WiMAX profil az előbbiektől eltérően 5; 7; 8,75; és $10 \mathrm{MHz}$ szélességü csatornákat javasol a 2,5 és a 3,5 GHz-es frekvenciasávokhoz, bár a SOFDMA $^{33}$ alkalmazásával ez dinamikusan változtatható $1,25 \mathrm{MHz}$-től egészen $20 \mathrm{MHz}$-ig. ${ }^{34}$

\footnotetext{
31 Time Division Duplex (időosztásos duplex)

32 Frequency Division Duplex (frekvenciaosztásos duplex)

33 Scalable Orthogonal Frequency Division Multiple Access (skálázható ortogonális frekvenciaosztásos többszörös hozzáférés)

34 Vass Zoltán: i. m.
} 
Ha a csatornát egyetlen vivővel szeretnénk átvinni, az nem lenne elég hatékony, mivel a sáv alsó és felső tartományában más-más csillapítási jellemzők, interferenciajelenségek stb. jelenhetnek meg. Ezt még adaptív szintszabályozással sem lehet kiküszöbölni, ezért megoldást az OFDM technológia amelyet eredetileg a 802.11a szabványhoz fejlesztettek ki - kínál, amely egyúttal kiküszöböli a többutas terjedésből adódó terjedésiidő-szórást és a szimbólumok közti interferenciaproblémákat is, így nagyobb lesz a sáv átviteli kapacitása. Az OFDM lényege, hogy a csatornát több, kisebb sávszélességü jelfolyamra osztja, amelyek mindegyike külön vivőfrekvenciával bír, majd ezeket az alvivőket ortogonálisan modulálja és összegzi. Ezzel a módszerrel elérhető, hogy a csatornát egyenletesen használjuk ki, így jobb jel-zaj viszonyt érünk el. Ha spektrális zavar áll fenn, akkor lehetőség van az egyes alvivők modulációjának egyszerüsítésére, vagy az adatátvitel leállítására, míg a többi alvivőn ugyanúgy folyhat a kommunikáció. Az SOFDMA ennek a továbbfejlesztése, amelyben az alkalmazási viszonyoknak megfelelően, rugalmasan változtatható a csatorna sávszélessége. Az alvivők száma megválasztható $(128,256,512,1024$ vagy 2048), miközben a szimbólum-időtartam és az alvivők közti frekvenciakülönbség fix. Mivel azonban az OFDMA és az SOFDMA különböző modulációs technikán alapszik, az SOFDMA nem kompatibilis az OFDM-mel.

A fejlett fizikairéteg-technológiák egy olyan gyüjtőfogalmat alkotnak, amelybe azokat a megoldásokat soroljuk, amelyek a szükre szabott spektrum nagyobb kihasználásához segítenek hozzá. Idetartoznak a különböző modulációs eljárások, hibajavító kódok, fejlett antennamegoldások, stb. A WiMAX esetén számos ilyen technológiát alkalmaznak, amelyek müszaki leírása több ezer oldal, ezért csak a legjelentősebbeket emeltem ki.

Első az adaptív moduláció, amely rugalmasan ötvözi a QPSK $^{35}$, a QAM16 ${ }^{36}$ és a QAM64 technológiákat, a vételi viszonyoknak megfelelóen. Amennyiben a bázisállomás és a felhasználói terminál között $\operatorname{LOS}^{37}$ kapcsolat van, elméletileg zavartalan a kommunikáció, és a leghatékonyabb (és egyben „legsűrübb”) modulációt alkalmazhatjuk. Gyakorlatilag viszont számolni kell a légköri csillapítással, amit az időjárási jelenségek jelentősen befolyásolnak - számít a páratartalom, a csapadék, a köd stb. A mindenhol az elérhető leghatékonyabb átviteli kapacitás elérése érdekében dolgozták ki az adaptív modulációt, amelynek lényege, hogy a távolság növekedésével és a

35 Quadrature Phase Shift Keying (kvadratúra fázisbillentyűzés)

36 Quadrature Amplitude Modulation (kvadratúraamplitúdó-moduláció)

37 Line of Sight (közvetlen optikai rálátás) 
vétel romlásával arányosan, vagyis a jel-zaj viszony $\left(\mathrm{SNR}^{38}\right)$ függvényében egyre egyszerübb (kisebb kapacitású), ám jobban fogható modulációt alkalmaz (1. számú ábra).

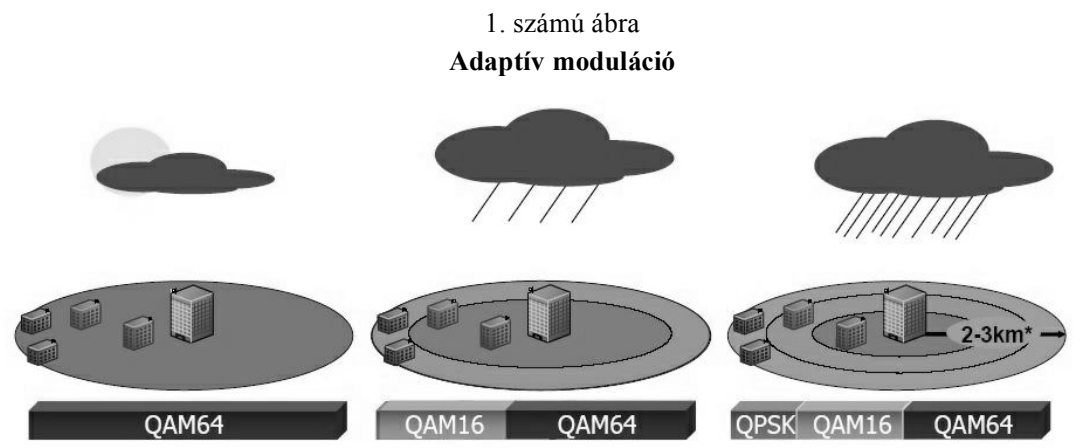

Forrás: Reza Golshan: Fixed and Mobile WiMAX OVerview. Fujitsu Microelectronics America, Inc., 2006, p. 16. http://www.fujitsu.com/downloads/MICRO/fma/pdf/esc_wimax06.pdf

A második technológiai megoldásnak NLOS környezetben van jelentősége. Ez lehet városi környezet, vagy akár hegyes-erdős, erősen tagolt terep is. Ilyen körülmények között a kisugárzott visszavert jelek különböző utakat futnak be, más-más idő alatt. A technológia lényege, hogy a többutas terjedésböl fakadó zavarokat, interferenciákat kiküszöbölje (2. számú ábra).

2. számú ábra

Többutas terjedés

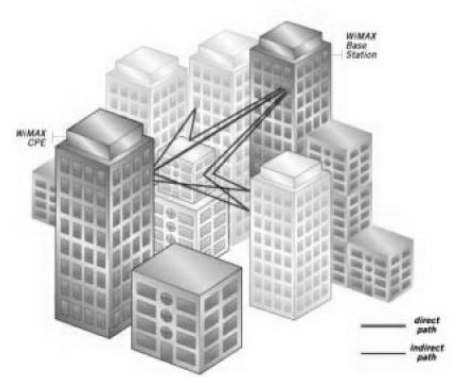

Forrás: WiMAX's technology for LOS and NLOS environments.

www.wimaxforum.org

38 Sound-to-Noise-Rate (jel-zaj viszony) 
A megoldásra a $\mathrm{MIMO}^{39}$ antennarendszer használata látszik jó megoldásnak. Ez azt jelenti, hogy több antennát használunk egyszerre, és az adó és vételi oldalon az egyes antennapárok között mintha külön-külön csatorna lenne. Ezek a csatornák azonban nem különbözők a rajtuk átvitt információ szempontjából, az csak más-más úton, eltérő terjedési idővel halad át rajtuk. A zavarok és interferencia kiszürésére speciális eljárást alkalmaznak, amelyet space-time kódolásnak nevezünk. A space-time kódolást 1998-ban Tarokh, Seshadri és Calderbank [TSC] fejlesztette ki MIMO rendszerekre. Lényege, hogy térbeli és időbeli kapcsolatot teremtsen a különböző antennákból különböző időpontokban sugárzott jelek között. Ezt a kapcsolatot arra használjuk, hogy minimalizáljuk a dekódolási hibákat a vevőnél. A space-time kódolás adó diversityt és teljesítménynyereséget jelent a sávszélesség feláldozása nélkül.

\section{Következtetések}

A rendőrség korszerü, perspektivikus infokommunikációs rendszerének kialakítása, a meglévő technikai lehetőségeink jobb kihasználása és a pénzügyi források hatékonyabb felhasználása érdekében javaslom a következő szempontok figyelembevételét:

- Az infokommunikáció minden területén törekedni kell a legkorszerübb adatvédelmi eljárások rendszertechnikai megvalósítására.

- A tevékenységirányítási rendszer struktúráját javaslom WiMAX alapra helyezni, ahol a szoftveresen programozható, gyors (VoIP képes) bázisállomások beszerzése javasolt a mikrohullámú gerincek és a területlefedő megoldásokra is.

- A megjelenő rádióképességek integrálása a WiMAX rendszerrel növeli a rendszer megbízhatóságát.

- Feladat végrehajtásakor egységeink megóvása érdekében a távoltelepült WiMAX csomópontok a kapcsolat tartására alkalmasak. Ebben az esetben a WiMAX területlefedö üzemmódban dolgozik.

- Rendszereink a digitalizáció növekedésével egyre inkább támadhatóvá válnak távoli hozzáféréssel is - ezért mindent meg kell tenni a kockázati tényezők csökkentése érdekében.

Az előbbi szempontok szerinti ajánlások, javaslatok figyelembevétele - megítélésem szerint - nagymértékben elősegítheti a rendőrség modernizációját, fejlesztési ütemének felgyorsítását.

39 Multiple Input Multiple Output (több bemenet, több kimenet) 